\title{
Proline levels, oxidative metabolism and photosynthetic pigments during in vitro growth and acclimatization of Pitcairnia encholirioides L.B. Sm. (Bromeliaceae)
}

\author{
C. F. Resende ${ }^{*}$, V. F. Braga ${ }^{a}$, P. F. Pereira ${ }^{a}$, C. J. Silva ${ }^{a}$, V. F. Vale ${ }^{a}$, R. E. Bianchetti ${ }^{a}$, \\ R. C. Forzza ${ }^{b}$, C. Ribeiro ${ }^{c}$ and P. H. P. Peixoto ${ }^{a}$
}

a'Laboratório de Fisiologia Vegetal, Departamento de Botânica, Instituto de Ciências Biológicas, Universidade Federal de Juiz de Fora - UFJF, Campus Universitário, Bairro Martelos, CEP 36036-900, Juiz de Fora, MG, Brazil

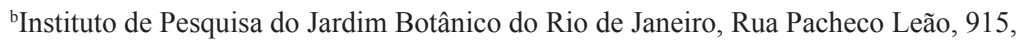

CEP 22460-030, Rio de Janeiro, RJ, Brazil

'Departamento de Biologia Geral, Centro de Ciências Biológicas, Universidade Federal de Viçosa - UFV, CEP 36571-000, Viçosa, MG, Brazil

*e-mail: cristianoig2004@hotmail.com

Received: September 15, 2014 - Accepted: December 16, 2014 - Distributed: February 29, 2016

(With 1 figure)

\begin{abstract}
This study aimed to evaluate the variation in the levels of proline, oxidative metabolism and photosynthetic pigments in plants of Pitcairnia encholirioides grown in vitro under different conditions and after acclimatization. The analyses were performed after 150 days of in vitro cultivation in MS media supplemented with $10 \mu \mathrm{M} \mathrm{GA}_{3}$ or $0.2 \mu \mathrm{M}$ NAA, sucrose at 15 or $30 \mathrm{~g} \mathrm{~L}^{-1}$, in test tubes which allowed gas exchange or in a hermetically sealed system, and 180 days after acclimatization. The in vitro maintenance in hermetically sealed flasks, with $\mathrm{GA}_{3}$ and $15 \mathrm{~g} \mathrm{~L}^{-1}$ sucrose had adverse metabolic effects, which was demonstrated by the lower proline and photosynthetic pigments accumulation and by the increase in antioxidant enzymes activities. After acclimatization, differences for proline and photosynthetic pigments were no longer found and the enzymatic activities ranged unevenly. The results suggest that the in vitro cultivation in media with $0.2 \mu \mathrm{M}$ NAA and $30 \mathrm{~g} \mathrm{~L}^{-1}$ sucrose, in test tubes capped with closures which allowed gas exchange, is more suitable for micropropagation of $P$. encholirioides, providing a prolonged maintenance of in vitro cultures and plantlets with superior quality for ex vitro development.
\end{abstract}

Keywords: enzymatic activity, oxidative stress, micropropagation, proline.

\section{Niveis de prolina, do metabolismo oxidativo e dos pigmentos fotossintéticos durante o crescimento in vitro e aclimatização de Pitcairnia encholirioides L.B. Sm. (Bromeliaceae)}

\section{Resumo}

Este trabalho objetivou avaliar a contribuição da prolina, do metabolismo oxidativo e dos pigmentos fotossintéticos na propagação in vitro e aclimatização de Pitcairnia encholirioides, uma bromélia criticamente ameaçada de extinção. As análises foram realizadas após 150 dias de cultivo in vitro em meio MS suplementado com $10 \mu \mathrm{M}$ de $\mathrm{GA}_{3}$ ou $0,2 \mu \mathrm{M}$ de ANA, 15 ou $30 \mathrm{~g} \mathrm{~L}^{-1}$ de sacarose, em tubos de ensaio que permitiam trocas gasosas ou em sistema hermeticamente vedado, e também 180 dias após aclimatização. A manutenção in vitro em frascos hermeticamente fechados, com $\mathrm{GA}_{3}$ e $15 \mathrm{~g} \mathrm{~L}^{-1}$ de sacarose apresentou efeito metabólico adverso, demonstrado pelo menor acúmulo de prolina e pigmentos fotossintéticos e também pelo aumento das atividades de enzimas antioxidantes. Após aclimatização, as diferenças para prolina e pigmentos fotossintéticos não foram mais encontradas e as atividades enzimáticas variaram de maneira desuniforme. Os resultados sugerem que o cultivo in vitro em meio com $0,2 \mu \mathrm{M}$ de $\mathrm{ANA}$ e $30 \mathrm{~g} \mathrm{~L}^{-1}$ de sacarose, em tubos fechados com tampas que permitem trocas gasosas, é mais adequado para a micropropagação de P. encholirioides, proporcionando uma manutenção prolongada das culturas in vitro e plântulas com qualidade superior para o desenvolvimento ex vitro.

Palavras-chave: atividade enzimática, estresse oxidativo, micropropagação, prolina. 


\section{Introduction}

In Brazil, bromeliads are popular ornamental plants often used in public and private gardens (Versieux and Wendt, 2007). Extractivism is one of the most important sources for supplying the consumer market (Coffani-Nunes and Forzza, 2000), contributing to the reduction of natural populations and extinction of some species (Pereira et al., 2008). Pitcairnia encholirioides L.B. Sm. is a quite rare bromeliad. For 70 years, it has only been recognized by the herbarium collection-type. However, in 2004, a population of around 900 plants was found on a much degraded rocky outcrop, in an area subject to fire and trampling by animals, located in Santa Maria Madalena, RJ, Brazil, suggesting that this species was among the most threatened in Rio de Janeiro (Martinelli and Forzza, 2006). Therefore, this species was included by the Biodiversitas Foundation in the critically endangered category (FUNDAÇÃO BIODIVERSITAS, 2005).

Micropropagation allows mass proliferation of threatened plants (Sarasan et al., 2006). As far as bromeliads are concerned, this biotechnology method provides an efficient commercial tool for the reintroduction of the plants, a fact which is extremely important for endangered species (Dal Vesco et al., 2011). In the last two decades, several studies regarding bromeliads have been published (Silveira et al., 2009; Santa-Rosa et al., 2013). After in vitro propagation, different systems are used in plantlet acclimatization (Deb and Imchen, 2010), a critical micropropagation phase which represents a limiting factor for its success (Chandra et al., 2010). Plant survival in field conditions depends on the quality of in vitro cultures (Faisal and Anis, 2009). The growth regulator, flask closure system and sucrose concentration in the culture medium affect plantlet survival in acclimatization, since these factors may affect the metabolism, modifying the morphological and physiological characteristics of the plants (Lucchesini and Mensuali-Sodi, 2004; Sáez et al., 2012). In addition to the modifications of in vitro culture conditions, several acclimatization procedures can be used, especially those which prevent water loss and biochemical disorders (Aragón et al., 2012).

Morphophysiological changes caused by in vitro culture, by light and due to hydric and osmotic stresses are the most important factors limiting plant acclimatization under field conditions, as they stimulate the oxidative metabolism by increasing the production of reactive oxygen species (ROS), especially the superoxide radicals $\left(\mathrm{O}_{2}{ }^{\circ}\right)$, hydrogen peroxide $\left(\mathrm{H}_{2} \mathrm{O}_{2}\right)$ and hydroxyl radicals $\left(\mathrm{OH}^{\circ}\right)$ (Bat'ková et al., 2008; Varshney and Anis, 2012). The $\mathrm{O}_{2}{ }^{\circ}$ spontaneously turns into $\mathrm{H}_{2} \mathrm{O}_{2}$, but this process is more efficient when catalyzed by superoxide dismutase (SOD). In the reaction, the $\mathrm{H}_{2} \mathrm{O}_{2}$ produced is scavenged by catalase (CAT) and peroxidase (POD), reducing the formation of hydroxyl radicals $\left(\mathrm{OH}^{*}\right)$ (Scandalios, 1993). Finally, polyphenoloxidase (PPO) catalyses the $\mathrm{O}_{2}$-dependent oxidation of catechols in quinones, and may synergistically act with POD, promoting its activation through the generation of $\mathrm{H}_{2} \mathrm{O}_{2}$ by the oxidation of phenolic compounds (Krishna et al.,
2008). Although less studied, PPO is an abundant plant enzyme (Agrawal and Purohit, 2012).

In acclimatization, several metabolic changes can be activated in an attempt to neutralize the damages caused by hydric stress, including the accumulation of different compatible solutes (Hoekstra et al., 2001; Mohammadkhani and Heidari, 2008). Proline is the primary accumulated metabolite in different stress conditions, which is essential for plant establishment and tolerance (Molinari et al., 2007; Liang et al., 2013).

Although there are several studies addressing the morphophysiological and biochemical changes which occur during plant acclimatization, to our knowledge, there have been no reports concerning the endangered bromeliad species. This study aimed to evaluate the variation in the levels of proline, oxidative metabolism and photosynthetic pigments in in vitro and ex vitro cultured $P$. encholirioides, seeking to increase the survival of these plants in the acclimatization procedures.

\section{Material and Methods}

\subsection{Plant material}

Cultures of Pitcairnia encholirioides L.B. Sm. previously established in vitro from seeds collected in the natural environment in Santa Maria Madalena, RJ, Brazil, under license from regulatory agencies, were used in the studies.

\subsection{Cultivation conditions}

The seedlings were grown in test tubes $(2.5 \times 15 \mathrm{~cm})$ in MS medium (Murashige and Skoog, 1962), supplemented with $30 \mathrm{~g} \mathrm{~L}^{-1}$ of sucrose (Sigma $\left.{ }^{\circledR}\right), 7 \mathrm{~g} \mathrm{~L}^{-1}$ of agar $\left(\operatorname{Sigma}^{\circledR}\right)$ and with $10 \mu \mathrm{M}$ gibberellic acid $\left(\mathrm{GA}_{3}\right)$ or $0.2 \mu \mathrm{M}$ $\alpha$-naphthalene-acetic acid (NAA), since both growth regulators promoted suitable developmental responses in previous micropropagation studies (data not shown). The culture medium $\mathrm{pH}$ was adjusted to $5.7 \pm 0.1$ before the autoclaving, performed for $20 \mathrm{~min}$, at $120^{\circ} \mathrm{C}$ and $1 \mathrm{~atm}$.

In addition to the effects of these growth regulators, the effects of two sucrose concentrations ( 15 or $30 \mathrm{~g} \mathrm{~L}^{-1}$ ) and two different closure systems for the test tubes were assessed, both by using polypropylene disposable closures, one of which permitted gas exchange (KAP-UTS (K25), Bellco $^{\circledR}, 25 \mathrm{~mm}$ ) and the other one (Sigma-Aldrich ${ }^{\circledR}$, $25 \mathrm{~mm}$ ) sealed with a stretchable self-adherent, $15-\mu \mathrm{m}$ thick PVC film (Vitaspenser, Goodyear ${ }^{\circledR}$ ), preventing ventilation by hermetically sealing the flask. The plants were kept for 150 days in a growth chamber under controlled temperature $\left(26 \pm 1{ }^{\circ} \mathrm{C}\right)$, photoperiod (16-8 h) and light intensity $\left(40 \mu \mathrm{mol} \mathrm{m}^{-2} \mathrm{~s}^{-1}\right)$, without subculturing. After in vitro cultivation in those different conditions, the plantlets were subjected to acclimatization in polystyrene trays of 128 cells, filled with Plantmax Hortaliças HT (Eucatex ${ }^{\circledR}$ ), moistened and covered with transparent plastic foil and kept under shade in a greenhouse, with humidity near $100 \%$ and a temperature of $27 \pm 3{ }^{\circ} \mathrm{C}$. After 35 days, the plants were moved to a greenhouse with a programmed misting system under plastic and shade (Sombrite ${ }^{\circledR} 75 \%$ ). After 150 days 
of in vitro cultivation and 180 days after transplantation to ex vitro conditions, leaf samples of the plantlets were obtained and subjected to different biochemical analysis and the plant development was visually compared among the treatments.

\subsection{Biochemical analysis}

In order to determine the proline contents, $0.3 \mathrm{~g}$ of fresh leaf tissues were weighed and immediately powdered in liquid nitrogen, followed by addition of $10 \mathrm{~mL}$ of sulfosalicylic acid at $3 \%(\mathrm{w} / \mathrm{v})$ and subsequent purification through Whatman $\mathrm{N}^{\circ} 2$ filter. The proline content was determined according to Bates et al. (1973). For the extraction of photosynthetic pigments, $0.1 \mathrm{~g}$ of fresh leaf was powdered in liquid nitrogen. Then, $25 \mathrm{~mL}$ of $80 \%$ acetone $(\mathrm{v} / \mathrm{v})$ was added, followed by filtration. The contents of photosynthetic pigments were determined according to Lichtenthaler (1987).

\subsection{Enzymatic analysis}

The extracts for determination of total protein levels and activities of SOD, CAT, POD and PPO were obtained by powdering $0.3 \mathrm{~g}$ of fresh leaf in liquid nitrogen, followed by addition of $10 \mathrm{~mL}$ of potassium phosphate buffer $0.1 \mathrm{M}, \mathrm{pH}$ 6.8, EDTA $0.1 \mathrm{mM}$ and PMSF $1 \mathrm{mM}$, filtration through four layers of cheesecloth and centrifugation at $10,000 \mathrm{~g}$ for 15 minutes at $4{ }^{\circ} \mathrm{C}$. The protein contents were analyzed by the enzymatic method of Lowry et al. (1951). SOD activity was measured according to Del Longo et al. (1993). The enzyme catalysis was carried out in a chamber illuminated by a $15 \mathrm{~W}$ fluorescent lamp for 3 min (Giannopolitis and Ries, 1977). Photoreduction of NBT to blue formazan was measured by the increase of absorbance at $560 \mathrm{~nm}$. One unit of SOD is defined as the amount of enzyme necessary to inhibit NBT photoreduction by $50 \%$ (Beauchamp and Fridovich, 1971). POD activity was measured according to Kar and Mishra (1976), using a molar extinction coefficient of $2.47 \mathrm{mM}^{-1} \mathrm{~cm}^{-1}$ (Chance and Maehly, 1955). PPO activity was measured as described for POD (Kar and Mishra, 1976). CAT activity was measured according to Havir and McHale (1987), as the absorbance decreased at $240 \mathrm{~nm}$, assuming a molar extinction coefficient of $36 \mathrm{M}^{-1} \mathrm{~cm}^{-1}$ (Anderson et al., 1995).

All the experiments were carried out in a completely randomized design with nine replications in a factorial $2 \times 2$ (sucrose at 15 or $30 \mathrm{~g} \mathrm{~L}^{-1} \times$ closures caps unsealed or hermetically sealed with $\mathrm{PVC}$ film), totaling 4 treatments for each growth regulator ( $\mathrm{GA}_{3}$ or NAA). The data were processed and analyzed using ANOVA. The means were compared by the Scott-Knott test at 5\% probability. The statistical analysis were performed using the SAEG program (System for Statistical Analysis, version 9.1, UFV, Brazil).

\section{Results}

In qualitative analysis, performed after 150 days of in vitro culture, it was observed that plantlets grown in culture medium with NAA and capped with closures allowing gas exchange showed best growth and morphological development (Figure 1a). In this micropropagation stage, there was considerable loss of explants due to senescence ( $57.6 \%$ on average). However, during acclimatization, the plantlets mortality was very low ( $11.3 \%$ on average). After transfer to ex vitro conditions, the Pitcairnia encholirioides plantlets showed typical development, without morphological alterations (Figure 1b).

In the analysis performed with the leaves of the in vitro plantlets, the proline contents oscillated specifically for each growth regulator (NAA or $\mathrm{GA}_{3}$ ) in response to sucrose concentrations (Table 1). Significant differences were found only in materials from plantlets maintained in culture media supplemented with NAA, with high proline contents in tissues kept in the presence of $30 \mathrm{~g} \mathrm{~L}^{-1}$ sucrose, regardless the type of closure. In this concentration, in hermetically sealed culture tubes, proline accumulation was $32 \%$ higher than in the presence of $15 \mathrm{~g} \mathrm{~L}^{-1}$ sucrose. However, in culture media containing $\mathrm{GA}_{3}$, this high proline content was not found in the presence of $30 \mathrm{~g} \mathrm{~L}^{-1}$ sucrose. After acclimatization, despite the use of different growth regulators and sucrose concentrations during the in vitro stage, significant differences in proline contents were not found among the treatments (Tables 1 and 2).

In general, the enzymatic activities of SOD, CAT and PPO were higher in plantlets cultured in media containing $15 \mathrm{~g} \mathrm{~L}^{-1}$ sucrose, regardless of the growth regulator and the closure system, except for the PPO in the presence of $\mathrm{GA}_{3}$ (Table 1). For POD, however, an opposite tendency was found. In acclimatized plantlets from culture media supplemented with NAA, in general, the CAT, POD and PPO activities were significantly lower in tissues from plantlets cultured in media containing $30 \mathrm{~g} \mathrm{~L}^{-1}$ sucrose, except for POD and PPO in plantlets maintained in unsealed tubes (Table 2). For SOD, an opposite tendency was found, but the differences were not significant, regardless of the closure system. In plantlets from culture media supplemented with $\mathrm{GA}_{3}$, a tendency for the SOD, CAT and POD activities to increase was observed in tissues from culture media containing the highest sucrose concentration, although, in some treatments, this increase was not significant. For PPO, an opposite tendency was found, but there were no significant differences. In this study, we notice the distinct responses of enzymatic activity to the sucrose concentrations when materials previously cultured in presence of $\mathrm{NAA}$ or $\mathrm{GA}_{3}$ were evaluated.

Regarding to the content of photosynthetic pigments (chlorophyll $a$, chlorophyll $b$, total chlorophyll and total carotenoids), significant differences were found in response to the closure systems used in vitro, with lower pigment accumulation in plantlets cultured in hermetically sealed tubes, especially in culture medium containing NAA (Table 3). In media with $\mathrm{GA}_{3}$, there was a lower pigment accumulation in hermetically sealed tubes containing $15 \mathrm{~g} \mathrm{~L}^{-1}$ sucrose. In media supplemented with $30 \mathrm{~g} \mathrm{~L}^{-1}$, most of the results showed no significant differences.

Concerning the sucrose effects, lower pigment accumulation was observed in tissues from culture 

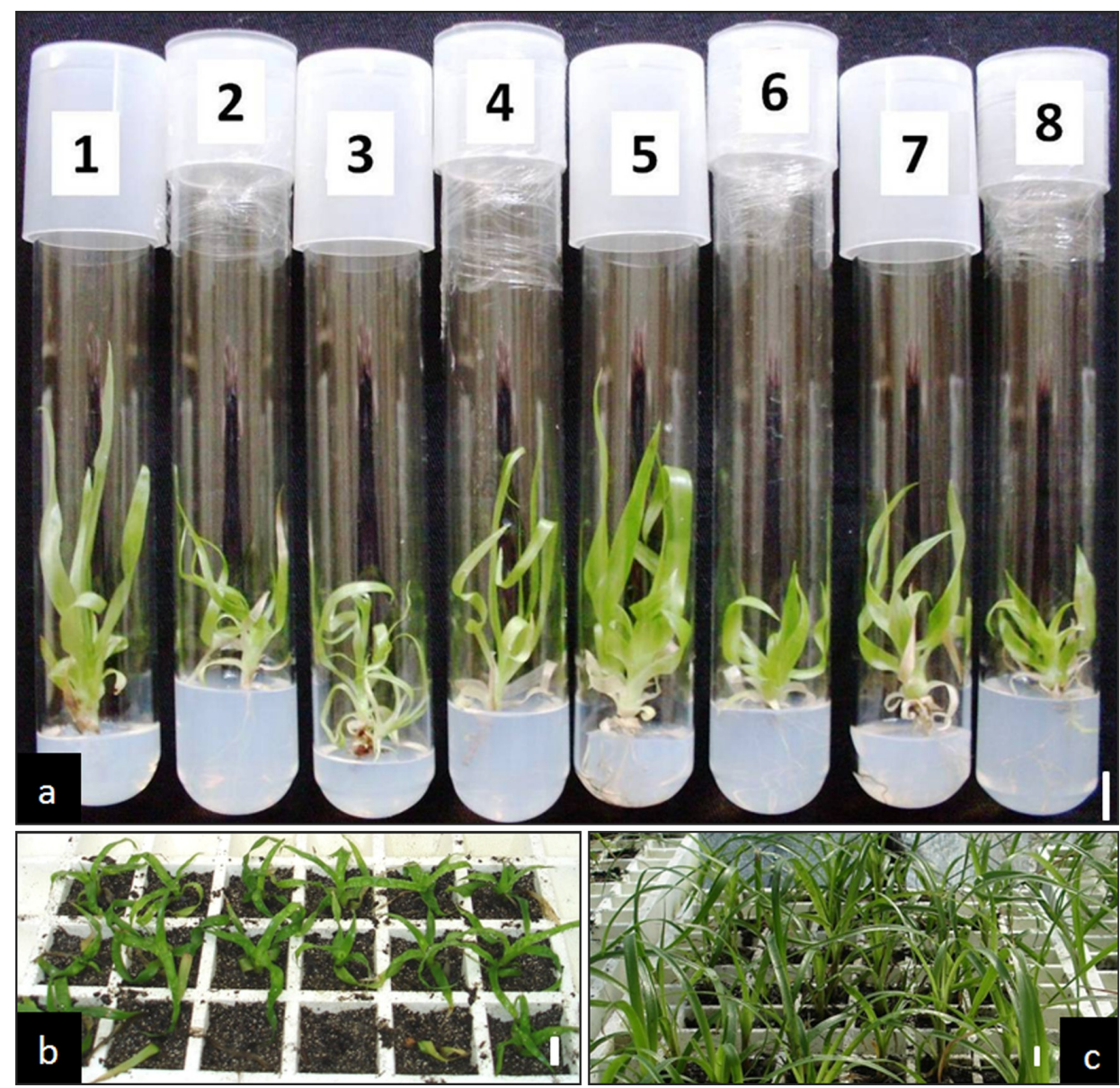

Figure 1. Pitcairnia encholirioides L.B. Sm. plantlets achieved after $150 \mathrm{~d}$ of in vitro culture (a), after $50 \mathrm{~d}$ (b) and $120 \mathrm{~d}$ (c) of acclimatization in a greenhouse. Treatments: (1) $10 \mu \mathrm{M} \mathrm{GA}_{3}, 15 \mathrm{~g} \mathrm{~L}^{-1}$ sucrose, unsealed closure; (2) $10 \mu \mathrm{M} \mathrm{GA}_{3}$, $15 \mathrm{~g} \mathrm{~L}^{-1}$ sucrose, sealed closure; (3) $10 \mu \mathrm{M} \mathrm{GA}_{3}, 30 \mathrm{~g} \mathrm{~L}^{-1}$ sucrose, unsealed closure; (4) $10 \mu \mathrm{M} \mathrm{GA} 3,30 \mathrm{~g} \mathrm{~L}-1$ sucrose, sealed closure; (5) $0.2 \mu \mathrm{M}$ NAA, $15 \mathrm{~g} \mathrm{~L}^{-1}$ sucrose, unsealed closure; (6) $0.2 \mu \mathrm{M}$ NAA, $15 \mathrm{~g} \mathrm{~L}^{-1}$ sucrose, sealed closure; (7) $0.2 \mu \mathrm{M}$ NAA, $30 \mathrm{~g} \mathrm{~L}^{-1}$ sucrose, unsealed closure; and 8) $0.2 \mu \mathrm{M}$ NAA, $30 \mathrm{~g} \mathrm{~L}^{-1}$ sucrose, sealed closure. Scale bar: $1 \mathrm{~cm}$.

Table 1. Proline $\left[\mu \mathrm{mol} \mathrm{g}{ }^{-1}\right.$ (f.m.)] contents and SOD $\left[\mathrm{U} \mathrm{mg}{ }^{-1}\right.$ (prot.)], CAT [mmol mg-1 (prot.) $\left.\mathrm{min}^{-1}\right]$, POD [ $\mu \mathrm{mol} \mathrm{mg}^{-1}$ (prot.) $\mathrm{min}^{-1}$ ] and PPO [ $\mu \mathrm{mol} \mathrm{mg} \mathrm{m}^{-1}$ (prot.) $\mathrm{min}^{-1}$ ] activities in leaf tissues of Pitcairnia encholirioides after 150 days of in vitro culture in presence of $\mathrm{GA}_{3}$ or NAA, in two sucrose concentrations $\left(15\right.$ or $\left.30 \mathrm{~g} \mathrm{~L}^{-1}\right)$ and under two types of closure (unsealed or sealed closure - US or S).

\begin{tabular}{lccccc}
\hline \multicolumn{1}{c}{ Treatment } & Proline & SOD & CAT & POD & PPO \\
\hline $\mathrm{GA}_{3}$ US 15 & $1.200 \mathrm{Aa}^{1}$ & $304.22 \mathrm{Aa}$ & $0.744 \mathrm{Aa}$ & $81.236 \mathrm{Ba}$ & $25.157 \mathrm{Aa}$ \\
$\mathrm{GA}_{3}$ US 30 & $1.124 \mathrm{Aa}$ & $189.09 \mathrm{Bb}$ & $0.583 \mathrm{Ba}$ & $97.658 \mathrm{Aa}$ & $26.523 \mathrm{Aa}$ \\
$\mathrm{GA}_{3}$ S 15 & $1.027 \mathrm{Ab}$ & $353.92 \mathrm{Aa}$ & $0.785 \mathrm{Aa}$ & $84.905 \mathrm{Ba}$ & $20.483 \mathrm{Ab}$ \\
$\mathrm{GA}_{3}$ S 30 & $0.925 \mathrm{Ab}$ & $257.83 \mathrm{Ba}$ & $0.627 \mathrm{Ba}$ & $93.248 \mathrm{Aa}$ & $20.000 \mathrm{Ab}$ \\
NAA US 15 & $1.008 \mathrm{Ba}$ & $261.33 \mathrm{Ab}$ & $0.911 \mathrm{Ab}$ & $68.303 \mathrm{Ba}$ & $17.321 \mathrm{Aa}$ \\
NAA US 30 & $1.166 \mathrm{Ab}$ & $200.57 \mathrm{Ba}$ & $0.683 \mathrm{Bb}$ & $91.902 \mathrm{Aa}$ & $11.432 \mathrm{Ba}$ \\
NAA S 15 & $1.093 \mathrm{Ba}$ & $358.77 \mathrm{Aa}$ & $1.160 \mathrm{Aa}$ & $74.779 \mathrm{Aa}$ & $13.815 \mathrm{Ab}$ \\
NAA S 30 & $1.447 \mathrm{Aa}$ & $222.81 \mathrm{Ba}$ & $0.822 \mathrm{Ba}$ & $81.874 \mathrm{Ab}$ & $10.140 \mathrm{Bb}$ \\
\hline
\end{tabular}

${ }^{1}$ In each growth regulator ( $\mathrm{GA}_{3}$ or NAA), means identified by capital letters compare the effects of sucrose concentration for each type of closure, and means identified by lower case letters compare the effects of the type of closure used in vitro at each sucrose concentration. Means identified by the same uppercase or lowercase letters do not differ significantly by the Scott-Knott test at $5 \%$ probability. 
Table 2. Proline $\left[\mu \mathrm{mol} \mathrm{g}{ }^{-1}\right.$ (f.m.) $]$ contents and SOD $\left[\mathrm{U} \mathrm{mg}^{-1}\right.$ (prot.)], CAT $\left[\mathrm{mmol} \mathrm{m} \mathrm{m}^{-1}\right.$ (prot.) $\left.\mathrm{min}^{-1}\right]$, POD $\left[\mu \mathrm{mol} \mathrm{mg}^{-1}\right.$ (prot.) $\left.\mathrm{min}^{-1}\right]$

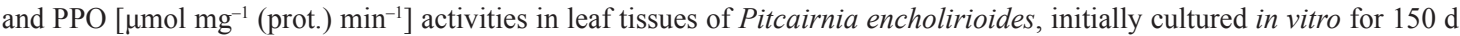
in the presence of $\mathrm{GA}_{3}$ or NAA, in two sucrose concentrations $\left(15\right.$ or $30 \mathrm{~g} \mathrm{~L}^{-1}$ ) and under two types of closure (unsealed or sealed closure - US or S), $180 \mathrm{~d}$ after acclimatization.

\begin{tabular}{llllrl}
\multicolumn{1}{c}{ Treatment } & Proline & SOD & CAT & \multicolumn{1}{c}{ POD } & PPO \\
\hline GA $_{3}$ US 15 & $1.425 \mathrm{~A}^{1}$ & $132.04 \mathrm{~A}$ & $0.994 \mathrm{~A}$ & $79.383 \mathrm{~B}$ & $34.842 \mathrm{~A}$ \\
$\mathrm{GA}_{3}$ US 30 & $1.309 \mathrm{~A}$ & $240.21 \mathrm{~A}$ & $1.231 \mathrm{~A}$ & $95.207 \mathrm{~A}$ & $32.562 \mathrm{~A}$ \\
$\mathrm{GA}_{3}$ S 15 & $1.193 \mathrm{~A}$ & $291.43 \mathrm{~A}$ & $1.232 \mathrm{~B}$ & $112.959 \mathrm{~A}$ & $52.356 \mathrm{~A}$ \\
$\mathrm{GA}_{3}$ S 30 & $0.914 \mathrm{~A}$ & $312.75 \mathrm{~A}$ & $1.962 \mathrm{~A}$ & $126.952 \mathrm{~A}$ & $44.273 \mathrm{~A}$ \\
NAA US 15 & $0.990 \mathrm{~A}$ & $285.36 \mathrm{~A}$ & $1.939 \mathrm{~A}$ & $98.739 \mathrm{~A}$ & $35.759 \mathrm{~A}$ \\
NAA US 30 & $1.375 \mathrm{~A}$ & $350.14 \mathrm{~A}$ & $1.509 \mathrm{~B}$ & $101.602 \mathrm{~A}$ & $35.185 \mathrm{~A}$ \\
NAA S 15 & $0.845 \mathrm{~A}$ & $241.28 \mathrm{~A}$ & $2.504 \mathrm{~A}$ & $145.465 \mathrm{~A}$ & $50.327 \mathrm{~A}$ \\
NAA S 30 & $1.147 \mathrm{~A}$ & $301.27 \mathrm{~A}$ & $1.568 \mathrm{~B}$ & $95.525 \mathrm{~B}$ & $41.461 \mathrm{~B}$ \\
\hline
\end{tabular}

${ }^{1}$ Means identified by the same letters (comparing the effects of sucrose concentration, in each growth regulator, for each type of closure) do not differ significantly by the Scott-Knott test at $5 \%$ probability.

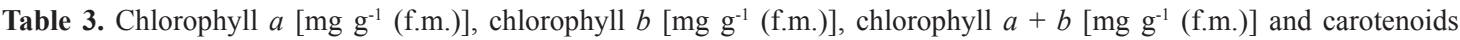
$\left[\mathrm{mg} \mathrm{g}^{-1}\right.$ (f.m.)] contents, chlorophyll $a / b$ ratio and chlorophyll $a+b /$ carotenoids ratio in leaf tissues of Pitcairnia encholirioides after $150 \mathrm{~d}$ of in vitro culture in presence of $\mathrm{GA}_{3}$ or NAA, in two sucrose concentrations $\left(15 \mathrm{or} 30 \mathrm{~g} \mathrm{~L}^{-1}\right)$ and under two types of closure (unsealed closure or sealed - US or S).

\begin{tabular}{lcccccc}
\hline \multicolumn{1}{c}{ Treatment } & Chl $\boldsymbol{a}$ & Chl $\boldsymbol{b}$ & Chl $\boldsymbol{a}+\boldsymbol{b}$ & Carot & Chl $\boldsymbol{a} /$ Chl $\boldsymbol{b}$ & $\begin{array}{c}\text { Chl } \boldsymbol{a}+\boldsymbol{b} / \\
\text { Carot }\end{array}$ \\
\hline $\mathrm{GA}_{3}$ US 15 & $0.912 \mathrm{Aa}^{1}$ & $0.343 \mathrm{Aa}$ & $1.256 \mathrm{Aa}$ & $0.284 \mathrm{Aa}$ & $2.651 \mathrm{Aa}$ & $4.415 \mathrm{Aa}$ \\
$\mathrm{GA}_{3}$ US 30 & $1.034 \mathrm{Aa}$ & $0.354 \mathrm{Ab}$ & $1.388 \mathrm{Aa}$ & $0.333 \mathrm{Aa}$ & $2.999 \mathrm{Aa}$ & $4.200 \mathrm{Ab}$ \\
$\mathrm{GA}_{3} \mathrm{~S} 15$ & $0.671 \mathrm{Bb}$ & $0.254 \mathrm{Ba}$ & $0.957 \mathrm{Bb}$ & $0.203 \mathrm{Bb}$ & $2.645 \mathrm{Aa}$ & $4.560 \mathrm{Aa}$ \\
$\mathrm{GA}_{3}$ S 30 & $1.222 \mathrm{Aa}$ & $0.490 \mathrm{Aa}$ & $1.713 \mathrm{Aa}$ & $0.359 \mathrm{Aa}$ & $2.506 \mathrm{Aa}$ & $4.765 \mathrm{Aa}$ \\
NAA US 15 & $0.678 \mathrm{Aa}$ & $0.281 \mathrm{Aa}$ & $0.960 \mathrm{Aa}$ & $0.186 \mathrm{Aa}$ & $2.407 \mathrm{Aa}$ & $5.141 \mathrm{Aa}$ \\
NAA US 30 & $0.408 \mathrm{Ba}$ & $0.212 \mathrm{Ba}$ & $0.621 \mathrm{Ba}$ & $0.128 \mathrm{Ba}$ & $1.922 \mathrm{Bb}$ & $4.843 \mathrm{Bb}$ \\
NAA S 15 & $0.298 \mathrm{Ab}$ & $0.220 \mathrm{Ab}$ & $0.737 \mathrm{Ab}$ & $0.144 \mathrm{Ab}$ & $2.345 \mathrm{Aa}$ & $5.122 \mathrm{Aa}$ \\
NAA S 30 & $0.273 \mathrm{Bb}$ & $0.133 \mathrm{Bb}$ & $0.407 \mathrm{Bb}$ & $0.079 \mathrm{Bb}$ & $2.042 \mathrm{Ba}$ & $5.135 \mathrm{Aa}$ \\
\hline
\end{tabular}

${ }^{1}$ In each growth regulator ( $\mathrm{GA}_{3}$ or NAA), means identified by capital letters compare the effects of sucrose concentration for each type of closure, and means identified by lower case letters compare the effects of the type of closure used in vitro at each sucrose concentration. Means identified by the same uppercase or lowercase letters do not differ significantly by the Scott-Knott test at $5 \%$ probability.

media supplemented with $30 \mathrm{~g} \mathrm{~L}^{-1}$ sucrose and NAA, regardless the closure type. From plants grown in culture media supplemented with $\mathrm{GA}_{3}$, the opposite effects were found, with lower pigments accumulation in tissues from plants cultured on media containing $15 \mathrm{~g} \mathrm{~L}^{-1}$ sucrose, in hermetically sealed vials (Table 3 ).

In the analysis performed on tissues from in vitro plantlets, significant effects in the chlorophyll $a / b$ ratio (chl $a / \mathrm{chl} b$ ) were found only in the plantlets maintained in presence of NAA, having lower ratios in tissues cultured in media with $30 \mathrm{~g} \mathrm{~L}^{-1}$ sucrose, regardless of the closure system (Table 3 ). When the closure systems effects were evaluated, differences were observed only for the chl $a / \mathrm{chl} b$ ratio in the presence of $30 \mathrm{~g} \mathrm{~L}^{-1}$ sucrose and NAA, with higher values found in the tissues from plants cultured in hermetically sealed tubes. For the chlorophyll $a+b /$ carotenoids ratio (chl $a+b /$ carot), differences were observed in response to the sucrose concentrations in plantlets from culture media containing NAA and kept in unsealed tubes, with higher values in the lower sucrose concentration. Regarding the closure system, irrespective of the growth regulator, significant differences were found in the culture media supplemented with $30 \mathrm{~g} \mathrm{~L}^{-1}$ sucrose, with higher values for chl $a+b$ /carot in materials from hermetically closed tubes (Table 3 ). In this study, differences in the photosynthetic pigment contents and in these ratios were no longer found after acclimatization (Table 4).

When the photosynthetic pigments of acclimatized plantlets were matched with pigments of in vitro plantlets, lower contents for chl $a$ were observed in all media, except for NAA, 15 and $30 \mathrm{~g} \mathrm{~L}^{-1}$ sucrose and sealed tubes. For chl $b$, they were lower in all cases, except for NAA, $30 \mathrm{~g} \mathrm{~L}^{-1}$ sucrose and sealed tubes. 
Table 4. Chlorophyll $a$ [mg g ${ }^{-1}$ (f.m.)], chlorophyll $b$ [mg g-1 (f.m.)], chlorophyll $a+b$ [mg g ${ }^{-1}$ (f.m.)] and carotenoids $\left[\mathrm{mg} \mathrm{g}^{-1}\right.$ (f.m.)] contents, chlorophyll $a / b$ ratio and chlorophyll $a+b /$ carotenoids ratio in leaf tissues of Pitcairnia encholirioides, initially cultured in vitro for $150 \mathrm{~d}$ in presence of $\mathrm{GA}_{3}$ or NAA, in two sucrose concentrations $\left(15 \mathrm{or}^{\left.30 \mathrm{~g} \mathrm{~L}^{-1}\right)}\right.$ and under two types of closure (unsealed closure or sealed - US or S), $180 \mathrm{~d}$ after acclimatization.

\begin{tabular}{lcccccc}
\hline \multicolumn{1}{c}{ Treatment } & Chl $\boldsymbol{a}$ & Chl $\boldsymbol{b}$ & Chl $\boldsymbol{a}+\boldsymbol{b}$ & Carot & Chl $\boldsymbol{a} / \mathbf{C h l} \boldsymbol{b}$ & $\begin{array}{c}\text { Chl } \boldsymbol{a}+\boldsymbol{b} / \\
\text { Carot }\end{array}$ \\
\hline $\mathrm{GA}_{3}$ US 15 & $0.385 \mathrm{~A}^{1}$ & $0.141 \mathrm{~A}$ & $0.527 \mathrm{~A}$ & $0.144 \mathrm{~A}$ & $2.723 \mathrm{~A}$ & $3.652 \mathrm{~A}$ \\
$\mathrm{GA}_{3}$ US 30 & $0.354 \mathrm{~A}$ & $0.126 \mathrm{~A}$ & $0.480 \mathrm{~A}$ & $0.139 \mathrm{~A}$ & $2.822 \mathrm{~A}$ & $3.457 \mathrm{~A}$ \\
$\mathrm{GA}_{3}$ S 15 & $0.356 \mathrm{~A}$ & $0.130 \mathrm{~A}$ & $0.486 \mathrm{~A}$ & $0.139 \mathrm{~A}$ & $2.794 \mathrm{~A}$ & $3.450 \mathrm{~A}$ \\
$\mathrm{GA}_{3}$ S 30 & $0.293 \mathrm{~A}$ & $0.107 \mathrm{~A}$ & $0.400 \mathrm{~A}$ & $0.108 \mathrm{~A}$ & $2.711 \mathrm{~A}$ & $3.718 \mathrm{~A}$ \\
NAA US 15 & $0.454 \mathrm{~A}$ & $0.161 \mathrm{~A}$ & $0.616 \mathrm{~A}$ & $0.171 \mathrm{~A}$ & $2.812 \mathrm{~B}$ & $3.595 \mathrm{~A}$ \\
NAA US 30 & $0.360 \mathrm{~A}$ & $0.107 \mathrm{~A}$ & $0.468 \mathrm{~A}$ & $0.132 \mathrm{~A}$ & $3.448 \mathrm{~A}$ & $3.535 \mathrm{~A}$ \\
NAA S 15 & $0.398 \mathrm{~A}$ & $0.132 \mathrm{~A}$ & $0.531 \mathrm{~A}$ & $0.145 \mathrm{~A}$ & $3.022 \mathrm{~A}$ & $3.630 \mathrm{~A}$ \\
NAA S 30 & $0.368 \mathrm{~A}$ & $0.138 \mathrm{~A}$ & $0.507 \mathrm{~A}$ & $0.151 \mathrm{~A}$ & $2.677 \mathrm{~A}$ & $3.344 \mathrm{~A}$ \\
\hline
\end{tabular}

${ }^{1}$ Means identified by the same letters (comparing the effects of sucrose concentration, in each growth regulator, for each type of closure) do not differ significantly by the Scott-Knott test at $5 \%$ probability.

\section{Discussion}

High levels of sucrose increased the osmotic pressure in the culture media, which may result in cell water stress. The osmotic adjustment is an important response to harmful conditions, which occurs through the accumulation of compatible solutes (Hoekstra et al., 2001; Evers et al., 2010), molecules that maintain the water absorptive capacity and improve the drought tolerance (Kishor et al., 1995). Proline accumulation occurs due to the increase in synthesis and reduction in degradation, being one of the most frequent physiological responses induced by osmotic stress in plants (Zhang et al., 2013).

In this study, the differences found in plants maintained in culture media supplemented with NAA, with high proline contents in tissues kept with $30 \mathrm{~g} \mathrm{~L}^{-1}$ sucrose, regardless the type of closure seems to be a result of the osmotic adjustment in response to hydric stress caused by the high sucrose level in culture media. The increase in proline synthesis in transgenic tobacco (Nicotiana tabacum) plants over-producing proline by elimination of feedback inhibition of P5CS, the enzyme that catalyzes the proline biosynthesis, provides higher tolerance to hyperosmotic stress, giving substantial evidence of the relationship between this amino acid and drought tolerance (Kishor et al., 1995; Hong et al., 2000). Carvalho et al. (2013) found that proline modifies the expression of genes related to the plant responses to water deficit. In addition to the effects as osmotic adjustment mediator, proline also contributes as a stabilizer for subcellular structures, free radical scavenger and redox buffer, being the most important structural protein constituent of cell wall (Reddy et al., 2004; Molinari et al., 2007; Verslues and Sharma, 2010). Al-Khayri and Al-Bahrany (2002) found similar results to those obtained in the present study for in vitro callus of rice (Oryza sativa), in which increases in proline level in response to high sucrose levels were also observed.

After acclimatization, no significant differences in proline contents were found among the treatments. This is an important evidence of $P$. encholirioides acclimatization competence, regardless of in vitro culture conditions. These results suggest that proline is more important to the osmotic metabolism in in vitro culture of $P$. encholirioides than after plantlets adaptation to ex vitro conditions.

The SOD is the first enzymatic barrier against the harmful effects of oxidative stress, converting the $\mathrm{O}_{2}$ into $\mathrm{H}_{2} \mathrm{O}_{2}$ (Alscher et al., 2002). In parallel, the CAT acts to reduce the $\mathrm{H}_{2} \mathrm{O}_{2}$ to $\mathrm{H}_{2} \mathrm{O}$ and $\mathrm{O}_{2}$, preventing the generation of more reactive radicals such as $\mathrm{OH}^{*}$ (Perl-Treves and Perl, 2002; Kibinza et al., 2011). CAT and SOD are the most efficient enzymes of antioxidant metabolism, since their combined actions convert hazardous molecules into $\mathrm{H}_{2} \mathrm{O}$ and $\mathrm{O}_{2}$, avoiding damage to cellular components (Scandalios, 1993). The results found in this study suggest a high ROS production in plantlets kept in vitro in presence of $15 \mathrm{~g} \mathrm{~L}^{-1}$ sucrose, which was probably a result of the hyperhydricity symptoms visually recognized, like a water-soaked appearance of the tissues, developed in the tissues of seedlings maintained in this condition, which required a high antioxidant activity for ROS neutralization. The inverse relationship between proline contents and POD activities, found by Kravić et al. (2013) in maize plants under osmotic stress, was not found in our study. In general, higher SOD and CAT activities were observed in materials kept in hermetically sealed tubes, where the relative humidity is close to $100 \%$, a condition which promotes the hyperhydricity, hypoxia and, consequently, oxidative stress. The higher SOD and CAT activities found in tissues from plantlets grown in vitro in hermetically sealed tubes suggest that the impaired gas exchange is harmful to oxidative plant metabolism and could promote increases in ROS generation, requiring increased antioxidant enzyme activity.

During acclimatization, the plantlets are subjected to several stresses in response to changes in environmental conditions, which occurs due to impaired stomata function and reduced cuticle deposition on cells, resulting in dehydration and increase in ROS production (Bat'ková et al., 2008). 
Despite that, after the transference to ex vitro conditions, the plantlets of $P$. encholirioides showed typical development, without morphological alterations, probably due to rustic bromeliad photosynthetic crassulacean acid metabolism, which is usually associated with improved drought tolerance and acclimatization capacity.

According to Gour et al. (2007), the chlorophyll content is one of the most important parameters for evaluation of the plant hardening after acclimatization. Carotenoids are also important in this phase, since they are required to protect the photosynthetic apparatus against damages caused by excess of radiant energy and contribute to non-enzymatic antioxidant defense systems (Perl-Treves and Perl, 2002; Pospíśilová et al., 2009). The results found in this work, with lower pigment accumulation in plantlets cultured in hermetically sealed tubes, especially in culture medium containing NAA, reinforce the hypothesis that the hermetic sealing of the vials could be detrimental to the development of autotrophic plants, reducing the efficiency and protection of the photosynthetic apparatus. Similar results were found by Chanemougasoundharam et al. (2004), with Solanum tuberosum, and by Mohamed and Alsadon (2010), for potato plants, for which the ventilation of the culture flasks contributed positively to the chlorophyll $b$ content, not interfering, however, on levels of chlorophyll $a$.

The lower pigment accumulation observed in tissues from the culture media supplemented with $30 \mathrm{~g} \mathrm{~L}^{-1}$ sucrose and NAA, regardless the closure type, is a typical response found in the literature, being attributed to the effects of sucrose on biosynthesis of photosynthetic pigments, which result in inhibition of chlorophyll biosynthesis and in vitro photosynthesis (Eckstein et al., 2012). Plantlets grown without sucrose show a higher photosynthetic rate because this is the only route to carbon fixation (Iarema et al., 2012).

For plants grown in the presence of $\mathrm{GA}_{3}$, the opposite effects was found, with lower pigments accumulation in tissues from plants cultured in media added with $15 \mathrm{~g} \mathrm{~L}^{-1}$ sucrose, in hermetically sealed vials. These results suggest that in this circumstance, the plantlets were subjected to more severe stressful conditions than in response to NAA. Since gibberellin synthesis inhibitors prevent the occurrence of hyperhydricity (Ziv, 1992), GA 3 can be associated with this morphologic disorder, which is enhanced by low osmotic pressure conditioned by the reduced sucrose concentration in the culture medium, which increases the water availability to the tissues. In this condition, the hyperhydricity is stimulated, being further enhanced by the use of closures which prevent the occurrence of gas exchange (Lai et al., 2005).

After acclimatization, differences in the photosynthetic pigment contents and in these ratios disappeared. These results are in agreement with those found by Kadleček et al. (2001), with tobacco, and indicate that the effects of in vitro conditions on the pigment contents may vanish after acclimatization and thus, for $P$. encholirioides, the alterations found in vitro would have a slight influence on photosynthesis after acclimatization. According to Pospíšilová et al. (2009), the chlorophyll contents could be higher or lower in acclimatized plants when compared with in vitro plantlets. The differences could be attributed to irradiation conditions, culture medium composition and in vitro $\mathrm{CO}_{2}$ concentration. In addition, the tissues sources also affect the results, since persistent leaves generally exhibit reduction in pigment contents after acclimatization, and, in contrast, younger leaves tend to accumulate more chlorophylls and carotenoids (Van Huylenbroeck et al., 2000; Carvalho et al., 2001; Dias et al., 2013). Faisal and Anis (2009), working with Rauvolfia tetraphylla found increases in chlorophylls $a$ and $b$ in young leaves developed after acclimatization. Borghezan et al. (2003), studying some genotypes of grapevine (Vitis spp.), observed in two of them a higher total chlorophylls content in plantlets from in vitro tissues than from acclimatized plantlets. However, the opposite was found in four other genotypes.

In this study, the acclimatization was carried out in protected conditions for 180 days, which may have contributed to the partial recovery of the plantlets through acclimatization. If the analysis had been performed as soon as the plantlets were removed from in vitro condition, the results might have been different. Although the recovery for photosynthetic pigments and proline has been observed after acclimatization, most of the results found in this study suggest that the maintenance of plantlets in hermetically sealed vials containing culture media supplemented with $\mathrm{GA}_{3}$ and $15 \mathrm{~g} \mathrm{~L}^{-1}$ sucrose is harmful for their further growth and development.

\section{Conclusions}

The results of this study suggest that plantlets grown in culture medium supplemented with $\mathrm{GA}_{3}$, at a low sucrose concentration and kept in hermetically sealed tubes were subjected to a higher oxidative stress than those maintained in the presence of NAA, higher sucrose level and kept in flasks that allowed gaseous exchange. This resulted from the increase in CAT and SOD activities and, conversely, by the reduction of the proline and photosynthetic pigment contents in response to the first treatment. After acclimatization with adequate moisture, temperature and shading conditions, differences among the tissues for proline and photosynthetic pigments disappeared and the enzyme activities ranged unevenly, so that there was no generalization about their remaining effects in the in vitro phase. It is believed, however, that if these plantlets were established directly in a natural environment, without a careful acclimatization period, they would have a lower chance of survival.

It is further assumed that Pitcairnia encholirioides plantlets kept in culture media containing $0.2 \mu \mathrm{M}$ NAA and $30 \mathrm{~g} \mathrm{~L}^{-1}$ sucrose, in test tubes capped with closures allowing a gas exchange, were morphophysiologically more suitable, thus could exhibit a higher survival in response to successive subcultures. These conditions allow a longer in vitro maintenance and a supply of physiologically improved plants for ex vitro development, which could contribute to conservation and reduce the threat of extinction of this species. 


\section{Acknowledgements}

We are thankful to the Fundação de Amparo à Pesquisa de Minas Gerais (FAPEMIG) for financial support to the project (CRA-APQ-01446-08) and for having provided undergraduate research scholarships to the third author, and Coordenação de Aperfeiçoamento de Pessoal de Nível Superior (CAPES) for providing master's degree scholarships for the first author. This work is part of the first author's Master Degree dissertation, presented in the Programa de Pós-Graduação em Ecologia of the Universidade Federal de Juiz de Fora (PGECOL-UFJF).

\section{References}

AGRAWAL, M. and PUROHIT, S., 2012. Changes in antioxidant enzymes activity during in vitro morphogenesis of carnation and the effect of antioxidants on plant regeneration. World Journal of Science and Technology, vol. 2, no. 7, pp. 87-92.

AL-KHAYRI, J.M. and AL-BAHRANY, A.M., 2002. Callus growth and proline accumulation in response to sorbitol and sucrose-induced osmotic stress in rice. Biologia Plantarum, vol. 45, no. 4, pp. 609-611. http://dx.doi.org/10.1023/A:1022380827034.

ALSCHER, R.G., ERTURK, N. and HEATH, L.S., 2002. Role of superoxide dismutases (SODs) in controlling oxidative stress in plants. Journal of Experimental Botany, vol. 53, no. 372, pp. 1331-1341. http://dx.doi.org/10.1093/jexbot/53.372.1331. PMid:11997379.

ANDERSON, M.D., PRASAD, T.K. and STEWART, C.R., 1995. Changes in isozyme profiles of catalase, peroxidase, and glutathione reductase during acclimation to chilling in mesocotylus of maize seedlings. Plant Physiology, vol. 109, no. 4, pp. 12471257. PMid: 12228666.

ARAGÓN, C., CARVALHO, L., GONZÁLEZ, J., ESCALONA, M. and AMANCIO, S., 2012. The physiology of ex vitro pineapple (Ananas comosus $\mathrm{L}$. Merr. Var MD-2) as $\mathrm{CAM}$ or $\mathrm{C}_{3}$ is regulated by the environmental conditions. Plant Cell Reports, vol. 31, no. 4, pp. 757-769. http://dx.doi.org/10.1007/s00299-011-1195-7. PMid:22134875.

BATES, L.S., WALDREN, R.D. and TEARE, I.D., 1973. Rapid determination of free proline for water stress studies. Plant and Soil, vol. 39, no. 1, pp. 205-207. http://dx.doi.org/10.1007/ BF00018060.

BAŤKOVÁ, P., POSPÍŠILOVÁ, J. and SYNKOVÁ, H., 2008. Production of reactive oxygen species and development of antioxidative systems during in vitro growth and ex vitro transfer. Biologia Plantarum, vol. 52, no. 3, pp. 413-422. http://dx.doi. org/10.1007/s10535-008-0085-5.

BEAUCHAMP, C. and FRIDOVICH, I., 1971. Superoxide dismutase: improved assays and an assay applicable to acrylamide gels. Analytical Biochemistry, vol. 44, no. 1, pp. 276-287. http:// dx.doi.org/10.1016/0003-2697(71)90370-8. PMid:4943714.

BORGHEZAN, M., MORAES, L.K.A., MOREIRA, F.M. and SILVA, A.L., 2003. Propagação in vitro e avaliação de parâmetros morfofisiológicos de porta-enxertos de videira. Pesquisa Agropecuária Brasileira, vol. 38, no. 7, pp. 783-789. http://dx.doi.org/10.1590/ S0100-204X2003000700001.

CARVALHO, K., CAMPOS, M.K.F., DOMINGUES, D.S., PEREIRA, L.F.P. and VIEIRA, L.G.E., 2013. The accumulation of endogenous proline induces changes in gene expression of several antioxidant enzymes in leaves of transgenic Swingle citrumelo. Molecular Biology Reports, vol. 40, no. 4, pp. 3269-3279. http:// dx.doi.org/10.1007/s11033-012-2402-5. PMid:23292076.

CARVALHO, L.C., OSÓRIO, M.L., CHAVES, M.M. and AMÂNCIO, S., 2001. Chlorophyll fluorescence as an indicator of photosynthetic functioning of in vitro grapevine and chestnut plantlets under ex vitro acclimatization. Plant Cell, Tissue and Organ Culture, vol. 67, no. 3, pp. 271-280. http://dx.doi. org/10.1023/A:1012722112406.

CHANCE, B. and MAEHLY, A.C., 1955. Assay of catalases and peroxidases. Methods in Enzymology, vol. 2, pp. 764-775. http:// dx.doi.org/10.1016/S0076-6879(55)02300-8.

CHANDRA, S., BANDOPADHYAY, R., KUMAR, V. and CHANDRA, R., 2010. Acclimatization of tissue cultured plantlets: from laboratory to land. Biotechnology Letters, vol. 32, no. 9, pp. 1199-1205. http://dx.doi.org/10.1007/s10529-010-0290-0. PMid:20455074.

CHANEMOUGASOUNDHARAM, A., SARKAR, D., PANDEY, S.K., AL-BISKI, F., HELALI, O. and MINHAS, J.S., 2004. Culture tube closure-type affects potato plantlets growth and chlorophyll contents. Biologia Plantarum, vol. 48, no. 1, pp. 7-11. http://dx.doi.org/10.1023/B:BIOP.0000024268.20248.33.

COFFANI-NUNES, J.V. and FORZZA, R.C., 2000. Bromélias. In: Anais do I Seminário Nacional de Recursos Florestais da Mata Atlântica: a exploração e utilização dos recursos, seus impactos sócio-econômicos atuais e potencialidade de manejo sustentável, 1999, São Paulo. Rio de Janeiro: Reserva da Biosfera, Fundação SOS Mata Atlântica, Jardim Botânico do Rio de Janeiro, EMBRAPA-CENARGEN, pp. 40-44.

DAL-VESCO, L.L., STEFENON, V.M., WELTER, L.J., SCHERER, R.F. and GUERRA, M.P., 2011. Induction and scale-up of Billbergia zebrina nodule cluster cultures: Implications for mass propagation, improvement and conservation. Scientia Horticulturae, vol. 128, no. 4, pp. 515-522. http://dx.doi.org/10.1016/j.scienta.2011.02.018.

DEB, C.R. and IMCHEN, T., 2010. An efficient in vitro hardening technique of tissue culture raised plants. Biotechnology, vol. 9, no. 1, pp. 79-83. http://dx.doi.org/10.3923/biotech.2010.79.83.

DEL-LONGO, O.T., GONZÁLEZ, C.A., PASTORI, G.M. and TRIPPI, V.S., 1993. Antioxidant defenses under hyperoxygenic and hyperosmotic conditions in leaves of two lines of maize with differential sensitivity to drought. Plant and Cell Physiology, vol. 34, no. 7, pp. 1023-1028.

DIAS, M.C., PINTO, G., CORREIA, C.M., MOUTINHOPEREIRA, J., SILVA, S. and SANTOS, C., 2013. Photosynthetic parameters of Ulmus minor plantlets affected by irradiance during acclimatization. Biologia Plantarum, vol. 57, no. 1, pp. 33-40. http://dx.doi.org/10.1007/s10535-012-0234-8.

ECKSTEIN, A., ZIĘBA, P. and GABRYŚ, H., 2012. Sugar and light effects on the condition of the photosynthetic apparatus of Arabidopsis thaliana cultured in vitro. Journal of Plant Growth Regulation, vol. 31, no. 1, pp. 90-101. http://dx.doi.org/10.1007/ s00344-011-9222-z.

EVERS, D., LEFÈVRE, I., LEGAY, S., LAMOUREUX, D., HAUSMAN, J.-F., ROSALES, R.O.G., MARCA, L.R.T., HOFFMANN, L., BONIERBALE, M. and SCHAFLEITNER, R., 2010. Identification of drought-responsive compounds in potato through a combined transcriptomic and targeted metabolite approach. Journal of Experimental Botany, vol. 61, no. 9, pp. 2327-2343. http://dx.doi.org/10.1093/jxb/erq060. PMid:20406784. 
FAISAL, M. and ANIS, M., 2009. Changes in photosynthetic activity, pigment composition, electrolyte leakage, lipid peroxidation, and antioxidant enzymes during ex vitro establishment of micropropagated Rauvolfia tetraphylla plantlets. Plant Cell, Tissue and Organ Culture, vol. 99, no. 2, pp. 125-132. http:// dx.doi.org/10.1007/s11240-009-9584-0.

FUNDAÇÃO BIODIVERSITAS, 2005 [viewed 29 May 2011]. Lista de espécies ameaçadas de extinção do Estado de Minas Gerais [online]. Belo Horizonte. Available from: http://www. biodiversitas.org.br/cepf/edital/flora_iucn.pdf

GIANNOPOLITIS, C.N. and RIES, S.K., 1977. Superoxide dismutases: I. Occurrence in higher plants. Plant Physiology, vol. 59, no. 2, pp. 309-314. http://dx.doi.org/10.1104/pp.59.2.309. PMid:16659839.

GOUR, V.S., SHARMA, S.K., EMMANUEL, C.J.S.K. and KANT, T., 2007. Stomata and chlorophyll content as marker traits for hardening of in vitro raised Balanites aegyptiaca (L.) Del. plantlets. National Academy Science Letters, vol. 30, no. $1-2$, pp. $45-47$

HAVIR, E.A. and MCHALE, N.A., 1987. Biochemical and developmental characterization of multiple forms of catalase in tobacco leaves. Plant Physiology, vol. 84, no. 2, pp. 450-455. http://dx.doi.org/10.1104/pp.84.2.450. PMid:16665461.

HOEKSTRA, F.A., GOLOVINA, E.A. and BUITINK, J., 2001. Mechanisms of plant desiccation tolerance. Trends in Plant Science, vol. 6, no. 9, pp. 431-438. http://dx.doi.org/10.1016/ S1360-1385(01)02052-0. PMid:11544133.

HONG, Z., LAKKINENI, K., ZHANG, Z. and VERMA, D.P.S., 2000. Removal of feedback inhibition of $\Delta^{1}$-pyrroline-5-carboxylate synthetase results in increased proline accumulation and protection of plants from osmotic stress. Plant Physiology, vol. 122, no. 4, pp. 1129-1136. http://dx.doi.org/10.1104/pp.122.4.1129. PMid:10759508.

IAREMA, L., CRUZ, A.C.F., SALDANHA, C.W., DIAS, L.L.C., VIEIRA, R.F., OLIVEIRA, E.J. and OTONI, W.C., 2012. Photoautotrophic propagation of Brazilian ginseng [Pfaffia glomerata (Spreng.) Pedersen]. Plant Cell, Tissue and Organ Culture, vol. 110, no. 2, pp. 227-238. http://dx.doi.org/10.1007/ s11240-012-0145-6.

KADLEČEK, P., TICHÁ, I., HAISEL, D., ČAPKOVÁ, V. and SCHÄFER, C., 2001. Importance of in vitro pretreatment for ex vitro acclimatization and growth. Plant Science, vol. 161, no. 4, pp. 695-701. http://dx.doi.org/10.1016/S0168-9452(01)00456-3.

KAR, M. and MISHRA, D., 1976. Catalase, peroxidase, and polyphenoloxidase activities during rice leaf senescence. Plant Physiology, vol. 57, no. 2, pp. 315-319. http://dx.doi.org/10.1104/ pp.57.2.315. PMid:16659474.

KIBINZA, S., BAZIN, J., BAILLY, C., FARRANT, J.M., CORBINEAU, F. and EL-MAAROUF-BOUTEAU, H., 2011. Catalase is a key enzyme in seed recovery from ageing during priming. Plant Science, vol. 181, no. 3, pp. 309-315. http://dx.doi. org/10.1016/j.plantsci.2011.06.003. PMid:21763542.

KISHOR, P.B.K., HONG, Z., MIAO, G.-H., HU, C.-A.A. and VERMA, D.P.S., 1995. Overexpression of $\Delta^{1}$-pyrroline-5carboxylate synthetase increases proline production and confers osmotolerance in transgenic plants. Plant Physiology, vol. 108, no. 4, pp. 1387-1394. PMid:12228549.

KRAVIĆ, N., MARKOVIĆ, K., ANĐELKOVIĆ, V., SUKALOVIĆ, V.H.-T., BABIĆ, V. and VULETIĆ, M., 2013. Growth, proline accumulation and peroxidase activity in maize seedlings under osmotic stress. Acta Physiologiae Plantarum, vol. 35, no. 1, pp. 233-239. http://dx.doi.org/10.1007/s11738-012-1068-x.

KRISHNA, H., SAIRAM, R.K., SINGH, S.K., PATEL, V.B., SHARMA, R.R., GROVER, M., NAIN, L. and SACHDEV, A., 2008. Mango explant browning: effect of ontogenic age, mycorrhization and pre-treatments. Scientia Horticulturae, vol. 118, no. 2, pp. 132-138. http://dx.doi.org/10.1016/j.scienta.2008.05.040.

LAI, C.-C., LIN, H.-M., NALAWADE, S.M., FANG, W. and TSAY, H.S., 2005. Hyperhydricity in shoot cultures of Scrophularia yoshimurae can be effectively reduced by ventilation of culture vessels. Journal of Plant Physiology, vol. 162, no. 3, pp. 355-361. http://dx.doi.org/10.1016/j.jplph.2004.07.015. PMid:15832688.

LIANG, X., ZHANG, L., NATARAJAN, S.K. and BECKER, D., 2013. Proline mechanisms of stress survival. Antioxidants \& Redox Signalling, vol. 19, no. 9, pp. 998-1001. http://dx.doi. org/10.1089/ars.2012.5074. PMid:23581681.

LICHTENTHALER, H.K., 1987. Chlorophylls and carotenoids: pigments of photosynthetic biomembranes. Methods in Enzymology, vol. 148, pp. 350-382. http://dx.doi.org/10.1016/0076-6879(87)48036-1.

LOWRY, O.H., ROSEBROUGH, N.J., FARR, A.L. and RANDALL, R.J., 1951. Protein measurement with the Folin phenol reagent. The Journal of Biological Chemistry, vol. 193, no. 1, pp. 265275. PMid:14907713.

LUCCHESINI, M. and MENSUALI-SODI, A., 2004. Influence of medium composition and vessel ventilation on in vitro propagation of Philly latifolia L. Scientia Horticulturae, vol. 100, no. 1-4, pp. 117-125. http://dx.doi.org/10.1016/j.scienta.2003.07.005.

MARTINELLI, G. and FORZZA, R.C., 2006. PitcairniaL'Hér. (Bromeliaceae): uma nova espécie, P. azouryi Martinelli andForzza, e observações sobre P. encholirioides L.B. Sm. Revista Brasileira de Botânica. Brazilian Journal of Botany, vol. 29, no. 4, pp. 603-607. http://dx.doi.org/10.1590/S0100-84042006000400010.

MOHAMED, M.A.-H. and ALSADON, A.A., 2010. Influence of ventilation and sucrose on growth and leaf anatomy of micropropagated potato plantlets. Scientia Horticulturae, vol. 123, no. 3, pp. 295-300. http://dx.doi.org/10.1016/j.scienta.2009.09.014.

MOHAMMADKHANI, N. and HEIDARI, R., 2008. Droughtinduced accumulation of soluble sugars and proline in two maize varieties. World Applied Sciences Journal, vol. 3, no. 3, pp. 448-453.

MOLINARI, H.B.C., MARUR, C.J., DAROS, E., CAMPOS, M.K.F., CARVALHO, J.F.R.P., BESPALHOK FILHO, J.C., PEREIRA, L.F.P. and VIEIRA, L.G.E., 2007. Evaluation of the stress-inducible production of proline in transgenic sugarcane (Saccharum spp.): osmotic adjustment, chlorophyll fluorescence and oxidative stress. Physiologia Plantarum, vol. 130, no. 2, pp. 218-229. http://dx.doi.org/10.1111/j.1399-3054.2007.00909.x.

MURASHIGE, T. and SKOOG, F., 1962. A revised medium for rapid growth and bioassay with tobacco tissue cultures. Physiologia Plantarum, vol. 15, no. 3, pp. 473-497. http://dx.doi. org/10.1111/j.1399-3054.1962.tb08052.x.

PEREIRA, A.R., PEREIRA, T.S., RODRIGUES, A.S. and ANDRADE, A.C.S., 2008. Morfologia de sementes e do desenvolvimento pós-seminal de espécies de Bromeliaceae. Acta Botanica Brasílica, vol. 22, no. 4, pp. 1150-1162. http://dx.doi. org/10.1590/S0102-33062008000400026.

PERL-TREVES, R. and PERL, A.,2002. Oxidative stress: an introduction. In: D. INZE and M. VAN MONTAGU, eds. Oxidative stress in plants. London: Taylor and Francis Books, pp. 1-32. 
POSPIŚSILOVÁ, J., HAISEL, D., SYNKOVÁ, H. and BAŤKOVÁSPOUSTOVÁ, P., 2009. Improvement of ex vitro transfer of tobacco plantlets by addition of abscisic acid to the last subculture. Biologia Plantarum, vol. 53, no. 4, pp. 617-624. http://dx.doi. org/10.1007/s10535-009-0113-0.

REDDY, A.R., CHAITANYA, K.V. and VIVEKANANDAN, M., 2004. Drought-induced responses of photosynthesis and antioxidant metabolism in higher plants. Journal of Plant Physiology, vol. 161 , no. 11 , pp. 1189-1202. http://dx.doi.org/10.1016/j. jplph.2004.01.013. PMid:15602811.

SÁEZ, P.L., BRAVO, L.A., LATSAGUE, M.I., SÁNCHEZ, M.E. and RÍOS, D.G., 2012. Increased light intensity during in vitro culture improves water loss control and photosynthetic performance of Castanea sativa grown in ventilated vessels. Scientia Horticulturae, vol. 138, pp. 7-16. http://dx.doi.org/10.1016/j. scienta.2012.02.005.

SANTA-ROSA, S., SOUZA, F.V.D., VIDAL, A.M., LEDO, C.A.S. and SANTANA, J.R.F., 2013. Micropropagation of the ornamental vulnerable bromeliads Aechmea blanchetiana and Aechmea distichantha. Horticultura Brasileira, vol. 31, no. 1, pp. 112-118. http://dx.doi.org/10.1590/S0102-05362013000100018.

SARASAN, V., CRIPPS, R., RAMSAY, M.M., ATHERTON, C., MCMICHEN, M., PRENDERGAST, G. and ROWNTREE, J.K., 2006. Conservation in vitro of threatened plants - progress in the past decade. In Vitro Cellular \& Developmental Biology. Plant, vol. 42, no. 3, pp. 206-214. http://dx.doi.org/10.1079/IVP2006769.

SCANDALIOS, J.G., 1993. Oxygen stress and superoxide dismutases. Plant Physiology, vol. 101, no. 1, pp. 7-12. PMid:12231660.

SILVEIRA, D.G., SOUZA, F.V.D., PELACANI, C.R., SOUZA, A.S., LEDO, C.A.S. and SANTANA, J.R.F., 2009. Micropropagation and in vitro conservation of Neoglaziovia variegate (Arr. Cam.)
Mez, a fiber producing bromeliad from Brazil. Brazilian Archives of Biology and Technology, vol. 52, no. 4, pp. 923-932. http:// dx.doi.org/10.1590/S1516-89132009000400016.

VAN-HUYLENBROECK, J.M., PIQUERAS, A. and DEBERGH, P.C., 2000. The evolution of photosynthetic capacity and the antioxidant enzymatic system during acclimatization of micropropagated Calathea plants. Plant Science, vol. 155, no. 1, pp. 59-66. http://dx.doi.org/10.1016/S0168-9452(00)00201-6. PMid:10773340.

VARSHNEY, A. and ANIS, M., 2012. Improvement of shoot morphogenesis in vitro and assessment of changes of the activity of antioxidant enzymes during acclimation of micropropagated plants of Desert Teak. Acta Physiologiae Plantarum, vol. 34, no. 3, pp. 859-867. http://dx.doi.org/10.1007/s11738-011-0883-9.

VERSIEUX, L.M. and WENDT, T., 2007. Bromeliaceae diversity and conservation in Minas Gerais State, Brazil. Biodiversity and Conservation, vol. 16, no. 11, pp. 2989-3009. http://dx.doi. org/10.1007/s10531-007-9157-7.

VERSLUES, P.E. and SHARMA, S., 2010. Proline metabolism and its implications for plant-environment interaction. The Arabidopsis Book / American Society of Plant Biologists, vol. 8, pp. 8. http://dx.doi.org/10.1199/tab.0140. PMid:22303265.

ZHANG, C.Y., WANG, N.N., ZHANG, Y.H., FENG, Q.Z., YANG, C.W. and LIU, B., 2013. DNA methylation involved in proline accumulation in response to osmotic stress in rice (Oryza sativa). Genetics and Molecular Research, vol. 12, no. 2, pp. 1269-1277. http://dx.doi.org/10.4238/2013.April.17.5. PMid:23661451.

ZIV, M., 1992. The use of growth retardants for regulation and acclimatization of in vitro plants. In: M. KARSSEN, L. C. VAN LOON and D. VREUGDENHIL, eds. Progress in plant growth regulation. Dordrecht: Kluwer Academic Publishers, pp. 809-817. 